\title{
Providing Skills and Support to Primary School Pupils in Content-Area Reading
}

\author{
Tuula Merisuo-Storm, Juli-Anna Aerila \\ University of Turku, Finland
}

\begin{abstract}
The aim of the study was to explore how well sixth-graders comprehend the textbooks used in history and natural sciences classes. 247 students took part in the study. Half of them read a text in their natural science book and the other half a text in their history book. After that, they each answered ten questions and explained ten words underlined in the text. The students had no difficulties in answering those questions to which the answers were directly found in the texts. However, questions requiring inference skills proved to be difficult. Explaining the meaning of words was an even more demanding task. It appears that there are many students who enter secondary school with poor reading comprehension skills. Therefore, students should be taught to comprehend texts related to different school subjects and strategies that help them to derive the meanings of unfamiliar words from textual contexts.
\end{abstract}

\section{Introduction}

Traditional textbooks are still a central source of information in today's content-area classes. To become academically successful, pupils have to learn to comprehend the contents of those books and find the main ideas contained in their chapters. Nevertheless, many pupils do not succeed at this task. Textbooks present limited information about several topics and use abstract concepts and vocabulary that is not always familiar to young readers. Consequently, they gain limited understanding and learn only superficial information. Even if the books include textual features that intend to help text comprehension, pupils are not aware of their purpose. They do not use the information that titles, sub-headings and pictures provide or pay attention to bold or italic print and coloured headings. In addition, as textbooks are often written concisely and state information as neutral facts, the pupils may find them uninteresting and tiresome. When they try to learn from texts that are too difficult and do not interest them, they become frustrated and their motivation to study declines.

Therefore, an important objective of teaching is to develop pupils' skills in reading, interpreting and utilizing different textbooks. Moreover, teachers should supplement textbooks with other texts to enrich the curriculum $[1,2,3,4]$.

For instance, history textbooks are more educational than exciting. While historical novels are popular with the reading public, history textbooks are generally considered dull. Historians write from a focused perspective, with history textbooks aiming to cover large parts of history. There have been several attempts to make history books more interesting and comprehensible to the pupils. This is, however, not easy, since these new books do not appear to lead to better text comprehension [5].

For the majority of children, the most common historical text thus remains the history textbook. They serve a number of important roles in the classroom, providing information and influencing the history curriculum. History textbooks are frequently used to introduce new topics and sometimes involve supplementary written materials. History textbooks rarely model the practices of historical literacy, tending to focus on facts, events, and people. This does not enhance the teaching and learning of historical thinking [5]. Focusing exclusively on memorising historical facts, and forgetting about thinking skills, runs counter to the subject's aim and is one reason for a lack of interest of history [6].

Pupils' reading skills also have a vital role in science learning. Scientific language has a precise structure and verbal reasoning, both of which demand special learning skills. This is a challenge for pupils who are not familiar with scientific language [7]. Literacy knowledge in science means knowing different text structures, how they differ from other texts, and how to use this knowledge as effectively as possible [8]. Narrative informational texts are a new category of informational texts that aim to be more readable than traditional informational-driven volumes [9]. These books are not commonly used in science education, even though they might be more comprehensible for young readers. They have more examples and illustrations than traditional textbooks and feature typical elements of narrative texts like characters, goals and resolution [7].

It would be worthwhile to test new methods when reading textbooks in content-area classes. For instance, literature circles are traditionally used when 
reading fiction, but Wilfong [10] has applied them to reading textbooks in science classes. His application offers educators an easy-access model to implement reading circles in different content areas. The chapters in a textbook are read in a given order by pupils who play particular roles. The reading circle is an alternative pedagogical approach in which pupils simultaneously learn the contents of textbook and develop their reading skills.

At the beginning of the reading circle, pupils read a chapter in a textbook individually. This gives the teacher time to concentrate on struggling readers and help them in reading. After that, collaborative rolebased activities begin. The pupils' roles are discussion manager, summariser, vocabulary enricher and webmaster. The role of the vocabulary enricher and webmaster are customised especially for non-fiction circles. The collaborative activity ends in a culminating activity, in which the roleplaying pupils present their text to the other pupils in various ways. Because of their structure and techniques, reading circles include not only discussing the ideas in textbooks with other pupils but also having pupils actively teaching other pupils. The results of this approach have been positive. The clear structure of the reading circle makes pupils' concentration on reading and learning new information easier. They learn new reading strategies and understand how important it is to know the definitions of words. In addition, they report enjoying the collaborative learning and the creative aspects of the culminating activity [10].

\section{Comprehension of non-fiction}

Reading comprehension is a complex process. When readers aim to understand a text, they construct meaning using their previous knowledge and experience and the information the text provides. The more background information related to the text that readers possess, the easier it is for them to understand the text. Each text is unique as regards its structure, genre, vocabulary and language $[11,12]$.

Young children are already able to use narrative modes of thinking for expressing and memorising things that are important to them. Therefore, a narrative format could be used to help young pupils to bridge the gap from the familiar to the less familiar. They understand information more readily if it is represented in story form and can use comprehension strategies that include doing things that they have done themselves or are able to imagine. However, if pupils read mainly fictional or even fanciful texts, they need to be introduced to science and social studies in order to develop realistic understandings of the physical and social world and how reading can also open doors to those areas of life [13].
Expository texts should already be employed even in preschool instruction; children should be taught expository comprehension skills such as the ability to recognise and reason with text structures. They benefit from learning basic structural patterns. The use of personal narratives that emphasise factual information with compare-and-contrast or problemand-solution structures can create an effective bridge between narrative and expository texts and improve children's comprehension of factual materials. However, considerable experience with non-fiction is needed to develop knowledge of that genre, including opportunities for reading, writing and discussion [14].

Research has shown that during the first years of school, children do not have many opportunities for reading and writing information texts in school $[15,16]$. Therefore, they often have difficulties in understanding information texts, which may well have complex structures and include new concepts $[17,18]$, and children need opportunities to read information texts to support the development of their reading comprehension skills and ability to use different comprehension strategies [13].

The comprehension of each different genre does not occur in the same way. Consequently, a pupil who understands one type of text with ease may well have difficulties in comprehending another kind of text. In addition, it is possible that comprehension instruction in one genre does not transfer, either fully or perhaps even at all, to another genre. Instruction should be tailored more closely to the real comprehension demands that pupils face when studying different school subjects. An important goal is to teach them how to use their comprehension skills not only in the familiar context in which they have learnt them but also in future contexts in which they will need them. Therefore, classroom teachers and the subject-area teachers should include comprehension instruction in their curricula [19].

However, Duke and Martin [19] and Parker and Hurry [20] argue that teachers often do not have explicit knowledge of the most significant reading comprehension strategies. It appears that direct oral questioning is the dominant strategy for teaching reading comprehension. However, a few minutes of asking and answering questions about a text passage is not enough. Often this kind of directive questioning produces answers that are correct but are also highly predictable and seldom assist children to develop more elaborated ideas. Even if the range of teachers' questions is wide and appropriate, children's role may still be too passive.

When reading expository texts, there are four key elements that are essential to comprehension processes: prior knowledge, inferential reasoning, self-regulation and motivation. When readers have prior knowledge of the topic and the structure of the text, it is easier for them to organize the text's ideas 
mentally and remember them later. Inferential reasoning refers to the readers' ability to read between the lines, making connections that are not clearly expressed in the text. The term self-regulated reading refers to self-questioning and repair processes. Skilful readers control their comprehension processes by choosing alternative strategies when others do not work [21].

According to Guthrie and Klauda [22] "the most overwhelming obstacle [to reading] is boredom". Skilful readers may also find the contents of a textbook uninteresting. However, pupils' interest in the topic of a text has a positive effect on their reading comprehension. When pupils consider the content of a text interesting, they actively want to understand what they are reading. This stimulates processes that are important in comprehension, such as making inferences based on the text and the reader's previous knowledge. Since there will be several occasions on which pupils will have to read and understand texts that they find uninteresting, it is imperative to teach them suitable reading strategies [23,24,25].

Teaching pupils how to read expository texts requires developing their awareness of text structure. The most common internal text structures of expository texts are description, sequence, compareand-contrast, cause-and-effect and problem-andsolution. Pupils simply must understand these concepts, which are foundational to learning. Each structure includes particular words that act as clues to help readers identify or label texts. Reader awareness of these structures helps them in mapping, anticipating, locating and processing the content of expository texts $[15,26]$.

Educators should teach pupils how to use the characteristic features of informational texts in order to facilitate comprehension. Pupils do not always pay sufficient attention to picture captions or text boxes that are not within the flow of the traditional left-toright, top-to-bottom reading in which they have been trained. They have to learn to understand the purpose of the distinctive features of informational texts, such as bold fonts, captions, text boxes, headings and subheadings, and how to use them. In addition, pupils need the skills to read graphics and texts that are presented in non-traditional formats $[2,26]$.

Summarising has proved to be a highly effective but also very difficult comprehension strategy. Skilful readers summarise while reading, which helps them memorise and connect the important ideas in a text. It creates learning that lasts because pupils have to dedicate time to reflecting and processing what they have read. Summarising is more than simply repeating what one has just read; it includes analysing information, discriminating between important and unimportant elements and encapsulating the information into a few short sentences. Nevertheless, many pupils struggle with determining the main ideas and themes of the text, combining similar ideas and synthesising them into a coherent whole. They often merely repeat most of the text or offer a very vague statement. A good summary should give a complete picture of the story, including only its important parts arranged in the same order as the text and indicating knowledge of how those elements are related [27,28].

It is also important that pupils learn to understand the difference between information and knowledge. For information to become knowledge, pupils need to reflect on it. Rote memorising has traditionally been part of subjects like history instruction. Memorising facts and birth and death dates without learning about the relevant time periods, the people themselves and the challenges they faced limits pupils' understanding of history [29].

School knowledge is constructed through expository language, and pupils may need help to be able to learn from expository texts. After four years of school, pupils are already expected to have good enough reading skills to enable them to use reading as a tool for acquiring new information in content areas. They move from a learning-to-read curriculum to a reading-to-learn curriculum that demands that they use reading to gain knowledge directly from their textbooks. Before the fourth grade, the majority of learning is accomplished by doing, seeing or hearing [7]. However, it has been reported that the majority of fourth-graders have not received enough instruction to read informational texts [30]. This may be due to the fact that many teachers are not accustomed to teaching literacy skills or diagnosing and addressing reading difficulties. Therefore, many fourth-grade students experience difficulties in reading informational textbooks and begin to fall behind their peers. Reading informational texts in different subjects requires different reading strategies and skills far beyond the simple skill of reading words and sentences [31].

Even after six years of school, some pupils have great difficulty in comprehending different texts as they move on to secondary school [4]. Prior knowledge about the topics of content-area textbooks may still be very limited, perhaps never consciously considered and might include misconceptions [13]. The essential capabilities necessary for understanding informational texts are prior knowledge to connect with what is read and learned, understanding the concepts of the subjects, metacognitive skills to monitor learning and word knowledge [32]. Vocabulary knowledge influences success both in and out of school [33]; it enables the pupils to build knowledge and learn through conceptual hooks. The promotion of these conceptual hooks is essential to learning and improving reading, writing, thinking and communicating skills [7].

When studying several different school subjects every day, pupils need a well-developed word 
knowledge base of each content area. However, the density of unfamiliar vocabulary prevents many pupils from comprehending the texts they read in different classes. These texts often contain lowfrequency words that do not appear in other contexts. Pupils do not encounter these words outside of their classes, which limits the multiple exposures the pupils need to assimilate word meanings and develop ownership of the various words they need to understand. Pupils need a thorough understanding of vocabulary because the words may represent essential concepts [34, 35].

Pupils should also learn that familiar words often have other meanings in different contexts. When asked what a word in a text means, they may give a definition that is correct in an everyday context but is inconsistent with the content of the text in question. Because the quotidian meaning of the word has long been familiar to them, they do not question its correctness [4]. This shows that their vocabulary knowledge is not deep enough. Breadth and depth are two key facets of vocabulary knowledge, so pupils should learn new meanings for familiar words in different content-area classes. Beyond their common meanings, many words have specialised meanings in particular subject areas: consider the word "family", with which all children are long familiar before they are asked to consider its placement below "order" and above "genus" in species classification. It is important to increase both the sheer number of words in pupils' vocabulary and the subtlety and extent of knowledge of individual words. Instructors should ensure that pupils have a solid conceptual understanding of content-area vocabulary, which is indispensable for success in any subject $[35,36]$.

Background experiences enable pupils to develop, expand and refine the concepts that words represent within the context of a certain subject. Pupils' understanding of textbooks in different subjects is based on vocabulary that is used to define the concepts and connect those concepts with the appropriate background knowledge. A lack of understanding the multiple meanings of familiar words inhibits understanding the meaning of a given word in, for example, the scientific context [7].

As noted above, textbooks include abstract concepts and vocabulary that is not familiar to young readers. If a significant word or concept is unknown, it is possible that the meaning of the whole text passage remains unclear to the readers. Pupils should be taught to derive the meaning of an unknown word from the written context. Strategies for deriving the meanings of words from context focus on using pieces of information that the text provides to infer the meanings of unknown words. The pupils' capability to derive a given word's meaning improves if they have an opportunity to explain the reasoning behind their own definitions or the correct definitions of the words. Their skills also develop when they hear the teacher and other pupils think aloud during the word explanation process [37,38].

In secondary school, textbooks become even more demanding and pupils' learning begins to rely more and more on their ability to read independently. Hence, it is essential that teachers at both the primary and secondary levels help pupils learn to comprehend the texts in their textbooks. They should discuss the typographic features of textbooks, such as boldface words, diagrams, maps and photographs with captions, with their pupils to make it easier for the readers to learn more content and meet the language demands of these more advanced and dense textbooks $[2,22,39,40]$.

\section{Boys' and girls' comprehension skills}

International assessments such as the OECD Program for International Student Assessment (PISA) and the Progress in International Reading Literacy Study (PIRLS) have shown that Finnish students have excellent reading skills. However, there is a significant gender gap in the results, as girls outperform boys in reading almost everywhere. This gap is especially large in some high-performing countries, where almost all the low achievers in reading are boys. It is disquieting that between PISA 2000 and PISA 2012 the gender gap in reading performance actually widened in 11 countries. Lowperforming boys are heavily over-represented among the group of students who fail to show basic levels of reading literacy. PISA results indicate that to be able to fulfil their potential, pupils need determination, motivation and self-confidence. Low achievers have a low level of engagement in reading. Students can only achieve at the highest levels when they are motivated to work and believe that they are in control of their own success and are capable of achieving at high levels $[41,42,43,44]$.

The differences in girls' and boys' skills are due mainly to their different attitudes towards reading. These are a result of gender differences in values, goals and out-of-school activities. To decrease the gender gap, new ideas intended to attract interest and engagement among boys in literary culture and that help them to find pleasure in reading are sorely needed [44]. It is also possible that boys do not display their true literacy skills within the set of reading practices that school entails, but rather in other - and for them more enjoyable - forms of reading. Many boys regard school literacy as unmasculine and thus unattractive [45]. It is worth remembering that a student's negative attitudes towards reading affect not only his or her own engagement in literacy, but also in many cases the literacy environment of the classroom as a whole [46]. 
Interest in the content of a text has an effect on reading comprehension, and it appears that boys are more affected than girls by their interest level in reading material. If a boy is interested in the content of a text, he wants to understand what he is reading. Regardless of the reason, girls understand both fiction and non-fiction better than boys, with the difference between the two genders' skills becoming even more significant in higher grades. One possible explanation is that many boys lack the ability to read texts effectively; they do not read texts from the beginning to the end but tend to dive in and out when reading $[23,24,25,47]$.

\section{The study}

The study has two goals: 1) how well sixthgraders (11-12 year-olds) comprehend the textbooks used in sixth-grade history and natural sciences classes and 2) how well they are able to derive the meaning of an unknown word from its written context. Altogether, 247 pupils (122 girls and 125 boys) from schools located in southern Finland took part in the study. About half of them read a text about whales in their natural science textbook and the other half a text about the Great Wall of China in their history textbook. Each subject was also divided roughly evenly between boys and girls.

Both chapters were four pages long; each page had pictures with captions. The chapter in the natural science textbook included information about the appearance and living conditions of whales and explained how they breathe and move. More detailed information was supplied about blue whales, toothed whales and dolphins. The chapter in the history textbook contained information about the ancient culture of China, such as the Great Wall, important Chinese inventions, Marco Polo and his long journey to China and how people in Europe reacted to his stories about China. After reading the text, the pupils answered ten questions and explained the meanings of ten words underlined in the text.

\section{Results}

The questionnaires related to both textbook chapters contained four questions to which the answers were found directly in the texts. Answering the next five questions in each case required combining different pieces of information from the text or making inferences. Answering the remaining question in each questionnaire required deeper understanding and reasoning.

In both groups, the pupils had no difficulties in answering those questions to which the answers were found directly in the texts. The easiest question related to the history book text were, "Why was the Great Wall of China built?" and "What were the inventions that the Chinese created?" Almost all pupils (98\%) answered the first question correctly, while $82 \%$ knew the second answer. The easiest questions related to the natural science textbook were, "How long the whales can be submerged?" and "What are krills?" Almost all pupils (94\%) answered the first question correctly, though the second proved a little more difficult, with only $77 \%$ giving a correct answer.

The questions that proved to be considerably more difficult required inference skills. For the pupils in the history book group, the most difficult question was, "Why did they not believe what Marco Polo related about China?" Only 2\% of pupils succeeded in finding a correct answer such as "China was in many aspects more advanced than the European countries and their inventions were unfamiliar to the Europeans." This question proved to be even more difficult than the question that required a deeper understanding of the text and a pupil's own reasoning: "Why was it a heavy blow to Chinese culture that the Mongolians became the rulers of China?" This question was answered correctly by only $11 \%$ of the pupils. The best example of a correct answer was: "Chinese people had until then been able to live in peace, but then the Mongolians could change their culture and habits because the Mongolians held the most important offices."

The most difficult question in the natural science group was, "In what way has the number of whales varied and what are the reasons behind that variation?" Only $9 \%$ of the pupils gave a correct answer that included all three pieces of information that were found in the text. However, one third of the pupils $(33 \%)$ answered the question that required a deeper understanding of the text and their own reasoning correctly: "What does the title of the chapter 'The Giants of The Pacific' mean?"

Often, the same pupils gave correct answers to the questions that were the most difficult $\left(\mathrm{r}=.336^{* *}, p=\right.$ $.002)$. On average, the girls in both groups were significantly more successful than the boys in answering the questions (history book group $t=2.73$, $p=.008$; natural science group $t=3.57, p=.000$ ). In the natural science group, the two pupils who answered all questions correctly were both girls. In the history group, more than one third $(37.5 \%)$ of the boys and $6.5 \%$ of the girls answered fewer than half the questions correctly.

The results show that for these sixth-graders the history text was more demanding than the natural science text, for both girls and boys. In the history book group, the best result in answering the questions was 17 out of 18 points, which was earned by a girl. There were four questions that fewer than one third of the pupils answered correctly. In the natural science book questionnaire, there was only one question that was equally difficult for the pupils. Although most pupils in Finland have rarely if ever 
seen whales, many pupils, especially girls, are interested in animals. Therefore, they had background information that helped them comprehend the natural science text. Figure 1 shows the girls' and boys' success in answering the questions related to the history book chapter.

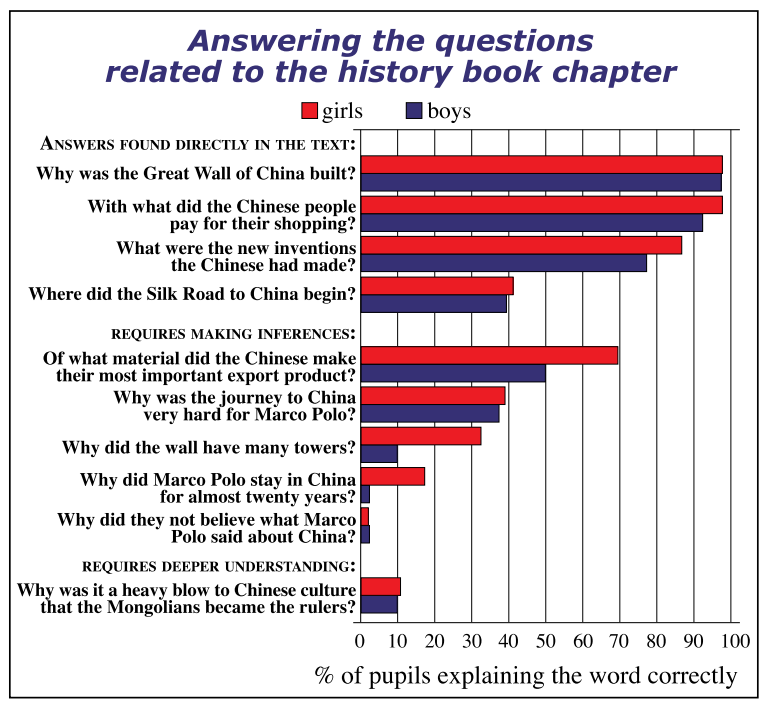

Figure 1. Girls' and boys' success in answering questions related to the history book chapter

Given the results, it is obvious that the pupils need teachers' guidance, especially when reading textbooks in history lessons. For instance, many would find it surprising that $61 \%$ of the pupils could not answer the question, "Where did Silk Road to China begin?" correctly, even though above that passage there was a map on which the road was clearly marked. It is equally surprising that, in the natural science group, two thirds $(66 \%)$ of the pupils did not understand the meaning of the chapter title. As noted above, it is important for teachers to discuss all the features of textbooks, such as chapter titles, headings and sub-headings, boldface words, diagrams and photographs with captions with their pupils [21].

Deriving the meaning of words and explaining them proved to be a demanding task for many pupils. Sometimes, it was difficult for pupils to explain words even if they clearly understood what those words meant. However, the results show that it was largely the same pupils who succeeded best in both answering the questions and explaining the words. There is a strong correlation between these two tasks $\left(\mathrm{r}=.390^{* *}, p=.000\right)$. When explaining words, the pupils were instructed to consider how they would explain them to a friend who did not know what the words mean. When considering the results, one must take into account that there are differences between the Finnish and English languages. Consequently, different words may be more difficult or common in one or the other. The words on both questionnaires included four nouns, three verbs, two adjectives, and one particle.

The easiest words to explain proved to be the concept valaiden laulu [whales' song] on the natural science group's questionnaire, as $91 \%$ of pupils gave the correct explanation. Most pupils (86\%) could also explain the word vaeltaa [migrate]. On the history book questionnaire, the easiest word was nuudeli [noodle], which $79 \%$ of pupils explained correctly. Almost as many pupils (77\%) explained the verb sanella [dictate] correctly.

Both textbooks included words that were not familiar to most pupils, and they could not derive their meanings from the context either. However, it is possible that even if the pupils understood a word, they could not always explain it. In the history book text, the most difficult word was the verb perua [withdraw]. Only $27 \%$ of the pupils gave an acceptable explanation. Only one third of the pupils (34\%) explained the word väkirikas correctly [populous; verbatim translation from Finnish 'rich of people'] correctly. This was the only word that the boys explained slightly more successfully than the girls. The particle lähinnä [mainly] in the sentence, "At the end of the $10^{\text {th }}$ century, gunpowder was mainly used in China for firework displays" was almost as difficult to explain. Only $37 \%$ of the pupils succeeded in that task.

In the science book text, the adjective virtaviivainen [streamlined] was used to describe the appearance of whales. Less than one fourth $(23 \%)$ of the pupils could explain that word. The noun haaremi [harem] was used to describe the group of female whales that a male whale has around him. Only $28 \%$ of the pupils explained it correctly. In addition, the particle jopa [as much as] proved difficult to explain, as a little more than one third of the pupils (37\%) explained it correctly. The results suggest that the pupils were not used to explaining words and concepts because often they used the same word in the explanation (e.g. "Withdraw means to withdraw something."; "Withdraw means to withdraw his words.").

The chapters of the textbooks that were used in this study included several other difficult words. In the history book wordlist, there were only two words that more than $70 \%$ of the pupils explained correctly. Four words were too difficult for at least half of the pupils and four words could be explained by $50-60 \%$ of the pupils. Only $3 \%$ of the pupils explained all the words correctly, while $5 \%$ of the pupils could not explain any of them, which could make understanding the chapter as a whole impossible or nearly so for that group. In word explanations, the difference between the two genders was not significant in the history book group. The girls' results were only slightly better than the boys' results (max. 10; girls: mean 5.4, SD 2.2; boys: mean 4.6, SD 2.4). Figure 2 shows the pupils' success in 
explaining the words related to the history book chapter.

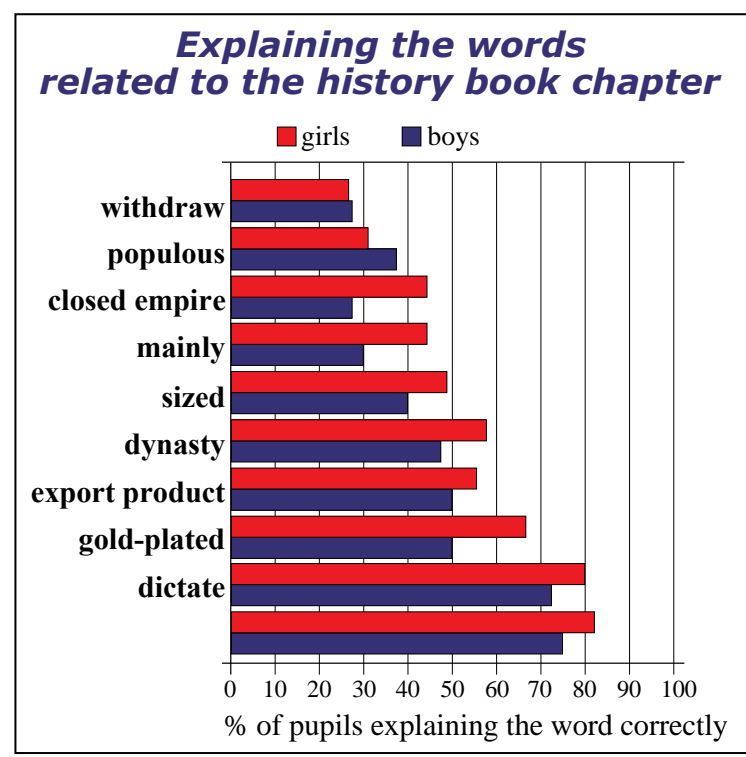

Figure 2. Girls' and boys' success in explaining the words related to the history book chapter

However, in the natural science book group the girls were notably more successful than boys (max. 10; girls: mean 6.2, SD 2.20; boys: mean 4.58, SD 2.39). The difference between the two genders was significant $(t=2.70, p=.008)$. Although the words in the natural science book seemed to be easier to explain than those in the history book, many pupils still had difficulties in understanding them. In the natural science book wordlist, there were four words that more than $70 \%$ of the pupils explained correctly. Four words were too difficult for at least half of the pupils and two words could be explained by $50-60 \%$ of the pupils. Only $3 \%$ of the pupils explained all words correctly, whereas $2 \%$ could not explain any of them.

The pupils who succeeded best in explaining the words were the same ones that had good results in answering the questions. For instance, in the history group the correlation between the success in these tasks was significant $\left(\mathrm{r}=.386^{* *}, p=.000\right)$.

\section{Conclusion}

The results show that pupils need help when reading the textbooks that are used in content-area classes. In this study, the sixth-grade history textbook in particular proved to be too difficult for many pupils. It is important that pupils be taught how to read and understand the textbooks in different school subjects. The pupils' results indicate that they were not used to answering questions that require the ability to make connections and inferences. In addition, many of them were happy to give an answer that was only one piece of information, although there were several relevant elements in the text. They were not able to use pictures as a source of information either.

Texts may be constructed differently and contain different vocabulary and concepts. Consequently, the pupils need to be taught how the text context helps to understand the meaning of an unfamiliar word. The results of the study showed that deriving the meaning of an unknown word from the written context was very difficult, indicating that the pupils had not had enough practice at that skill, because they often chose a meaning for a word that it carries in some other context.

As noted above, Guthrie and Klauda [22] argue that "the most overwhelming obstacle [to reading] is boredom". One reason for the fact that girls were significantly more successful than boys in explaining words in the natural science textbook may be that they found the text more interesting, just as it is possible that boys are more interested in history than in animals. The interest level in reading material has a stronger influence on boys than on girls. When boys consider the content of a text interesting, they are more likely to want to understand what they are reading. The use of versatile learning materials beyond traditional textbooks could help make learning easier and more interesting. For instance, pupils could find informational narrative texts more interesting and readable than traditional informational texts and textbooks [9].

The pupils who took part in the study moved on to secondary school the next autumn. There, the textbooks become even more demanding and pupils' learning begins to rely more and more on their ability to read independently. This study's results make it clear that it is important that the teachers in secondary school continue to help them to learn to comprehend the genres and terminology in the textbooks.

\section{References}

[1] R. Allington, "You Can't Learn Much from Books you can't Read", Educational Leadership 60(3), ASCD, Alexandria, VA, 2002, pp. 16-19.

[2] N. Bryce, "Meeting the Reading Challenges of Science Textbooks in the Primary Grades", Reading Teacher 64(7), International Literacy Association, Newark, DE, 2011, pp. 474-485.

[3] G. Conderman and N. Elf, "What's in this Book? Engaging Students through a Textbook Exploration Activity", Reading \& Writing Quarterly: Overcoming Learning Difficulties 23(1), Taylor \& Francis Group, London, 2007, pp. 111-116.

[4] T. Merisuo-Storm and M. Soininen, "Constructing a Research-Based Program to Improve Primary School Students' Reading Comprehension Skills", International 
Journal For Cross-Disciplinary Subjects In Education (IJCDSE) 3(3), Infonomics Society, Essex, 2012, pp. 755762.

[5] R.J. Paxton, “A Deafening Silence: History Textbooks and the Students Who Read Them", Review of Educational Research (69)3, American Educational Research Association, Washington, DC, 1999, pp. 315-339.

[6] R.J. Paxton, "Someone with Like a Life Wrote It: The Effects of Visible Author on High School History Students", Journal of Educational Psychology 89(2), American Psychology Association, Washington, DC, 1997, pp. 235-250.

[7] W. Rupley and S. Slough, "Building Prior Knowledge and Vocabulary in Science in the Intermediate Grades: Creating Hooks for Learning". Literacy Research and Instruction 49(2), Association of Literacy Educators and Researchers, Orlando, FL, 2010, pp. 99-112.

[8] E.B. Moje, T. Collazo, R. Carrillo, and R.W. Marx, "Maestro, what is 'quality': Language, literacy, and discourse in project-based science", Journal of Research in Science Teaching 38(4), National Association for Research in Science Teaching, Reston, VA, 2001, pp. 469-498.

[9] D.J. Ford, N.W. Brickhouse, P. Lottero-Perdue, and J. Kittleson, "Elementary girls' science reading at home and school", Science Education 90(2), Wiley Periodicals, Hoboken, NJ, 2006, pp. 270-288

[10] L.G. Wilfong, "Textmasters: Bringing Literature Circles to Textbook Reading Across the Curriculum", Journal of Adolescent \& Adult Literacy 53(2), International Literacy Association, Newark, DE, 2009, pp. 164-171.

[11] S.M. Blair-Larsen and K.M. Vallance, "Comprehension Instruction in a Balanced Reading Classroom", In S.M. Blair-Larsen \& K.A. Williams (Eds.) The Balanced Reading Program: Helping All Students Achieve Success. Newark, DE: International Reading Association, Newark, DE, 2004, pp. 37-52.

[12] L.S. Pardo, "What Every Teacher Needs to Know about Comprehension", The Reading Teacher 58(3), International Literacy Association, Newark, DE, 2004, pp. 272-280

[13] J. Brophy and J. Alleman, "Meaningful social studies for elementary students", Teachers and Teaching 15(3), International Study Association on Teachers and Teaching, Reading, 2009, pp. 357-376.

[14] B. Culatta, K.M. Hall-Kenyon, S. Black, "Teaching Expository Comprehension Skills in Early Childhood Classrooms", Topics in Language Disorders 30(4), Wolters Kluwer Health, Amsterdam, 2010, pp. 323-338.

[15] Z. Fang, "Going Beyond the Fab Five: Helping Students Cope with the Unique Linguistic Challenges of Expository Reading in Intermediate Grades", Journal of Adolescent \& Adult Literacy 51(6), International Literacy Association, Newark, DE, 2008, pp. 476-487.
[16] D.R. Reutzel, J.A. Smith, and P.S. Fawson, “An Evaluation of two Approaches for Teaching Reading Comprehension Strategies in the Primary Years using Science Information Texts", Early Childhood Research Quarterly 20, Elsevier, Amsterdam, 2005, pp. 276-305.

[17] R.M. Best, R.G. Floyd, and D.S. Mcnamara, "Differential Competences Contributing to Children's Comprehension of Narrative and Expository Texts", Reading Psychology 29(2), Taylor \& Francis Group, London, 2008, pp. 137-164.

[18] J.P. Williams, K.M. Hall, K.D. Lauer, K.B. Stafford, L.A. Desisto, and J.S. deCani, "Expository Text Comprehension in the Primary Grade Classroom", Journal of Educational Psychology 97(4), American Psychology Association, Washington, DC, 2005, pp. 538-550.

[19] N.K. Duke and N.M. Martin, "Comprehension Instruction in Action", In C.C. Block and S.R. Parris (Eds.) Comprehension Instruction, Research-Based Best Practices. Solving Problems in the Teaching of Literacy. Guilford Press, New York, NY, 2008, pp. 241-257.

[20] M. Parker and J. Hurry, "Teachers' Use of Questioning and Modelling Comprehension Skills in Primary Classrooms", Educational Review 59(3), Taylor \& Francis Group, London, 2007, 299-314.

[21] J. Coiro and E. Dobler, "Exploring the Online Reading Comprehension Strategies used by Sixth-Grade Skilled Readers to Search for and Locate Information on the Internet", Reading Research Quarterly 42(2), International Literacy Association, Newark, DE, 2007, pp. 214-257.

[22] J.T. Guthrie and K.L. Klauda, "Making Textbook Reading Meaningful", Educational Leadership 69(6), ASCD, Alexandria, VA, 2012, pp. 64-68.

[23] J.V. Oakhill and A. Petrides, "Sex Differences in The Effects of Interest on Boys' and Girls' Reading Comprehension", British Journal of Psychology 98(2), The British Psychological Society, London, 2007, pp. 223-235.

[24] L. Prado and L.A. Plourde, "Increasing Reading Comprehension through the Explicit Teaching of Reading Strategies: Is there a Difference among the Genders?", Reading Improvement 48(1), Project Innovation, Mobile, AL, 2011, pp. 32-43.

[25] K.J. Topping, J. Samuels, and T. Paul, "Independent Reading: The Relationship of Challenge, Non-Fiction and Gender to Achievement", British Educational Research Journal 34(4), Taylor \& Francis Group, London, 2008, pp. $505-52$.

[26] K.M. Hall-Kenyon and S. Black, "Learning From Expository Texts. Classroom-Based Strategies for Promoting Comprehension and Content Knowledge in the Elementary Grades", Topics in Language Disorders 30(4), Wolters Kluwer Health, Amsterdam, 2010, pp. 339-349.

[27] H.L. Diehl, "Snapshots of our journey to thoughtful literacy", The Reading Teacher 59(1), International Literacy Association, Newark, DE, 2005, pp. 56-69. 
[28] C. Westby, B. Culatta, B. Lawrence, and K.M. HallKenyon, "Summarixing expository texts", Topics in Language Disorders 30(4), Wolters Kluwer Health, Amsterdam, 2010, pp. 275-287.

[29] A. Goudvis \& S. Harvey, "Teaching for historical literacy", Educational Leadership 69(6), ASCD, Alexandria, VA, 2012, pp. 52-57.

[30] N.K. Duke, "3.6 minutes per day: The scarcity of informational texts in first grade", Reading Research Quarterly (35), International Literacy Association, Newark, DE, 2000, pp. 202-224.

[31] J.S. Chall and V.A. Jacobs, "Poor children's fourthgrade slump", American Educator 2(1), American Federation of Teachers, Washington, DC, 2003, pp. 14-15, 44.

[32] D. Gardner, "Children's immediate understanding of vocabulary: Contexts and dictionary definitions", Reading Psychology 28(4), Taylor \& Francis Group, London, 2007, pp. 331-373.

[33] W.H. Rupley, W.D. Nichols, and T.R. Blair, "Language and cultore in literacy instruction: Where have they gone?" The Teacher Educator 43(3), Ball State University, Muncie, IN, 2008, pp. 48-56.

[34] A. Hairrell, D. Simmons, E. Swanson, M. Edmonds, S. Vaughn, and W.H. Rupley, "Translating Vocabulary Research to Social Studies Instruction: Before, during, and after Text-Reading Strategies", Intervention in School and Clinic, 46(4), Hammill Institute on Disabilities, Austin, TX, 2011, pp. 204-210.

[35] J.M. Harmon, W.B. Hedrick, and K.D. Wood, "Research on Vocabulary Instruction in the Content Areas: Implications for Struggling Readers", Reading and Writing Quarterly 21(3), Taylor \& Francis Group, London, 2005, pp. 261-280.

[36] G.P. Ouellette, "What's Meaning Got to Do With It: The Role of Vocabulary in Word Reading and Reading Comprehension", Journal of Educational Psychology 98(3), American Psychological Association, Washington, DC, 2006, pp. 554-566.

[37] K. Cain, "Deriving Word Meanings from Context: Does Explanation Facilitate Contextual Analysis?", Journal of Research In Reading 30(4), The United Kingdom Literacy Association, London, 2007, pp. 347359.

[38] M. Tomesen and C. Aarnoutse, "Effect of an Instructional Programme for Deriving Word Meanings", Educational Studies 24(1), Taylor \& Francis Group, London, 1998, pp. 107-128.

[39] K. Garber-Miller, "Playful Textbook Previews", Journal of Adolescent \& Adult Literacy 50(4), International Literacy Association, Newark, DE, 2006, pp. 284-288.

[40] E. Swanson, M.S. Edmonds, A. Hairrell, S. Vaughn, and D.C. Simmons, "Applying a Cohesive Set Of
Comprehension Strategies to Content-Area Instruction", Intervention In School \& Clinic 46(5), SAGE Publishing, London, 2011, pp. 266-272.

[41] J. Kupari, S. Sulkunen, J. Vettenranta, and K. Nissinen, Enemmän iloa oppimiseen. Neljännen luokan oppilaiden lukutaito sekä matematiikan ja luonnontieteiden osaaminen. Kansainväliset PIRLS- ja TIMSS-tutkimukset Suomessa. Finnish Institute for Educational Research, University of Jyväskylä, 2012.

[42] I.V.S. Mullis, M.O. Martin, A.M. Kennedy, K.L.Trong, and M. Sainsbury, PIRLS 2011 Assessment Framework. International Association for the Evaluation of Educational Achievement (IEA), Amsterdam, 2009.

[43] OECD. PISA 2012 Results in Focus. What 15-yearolds know and what they can do with what they know. OECD, Paris, 2013.

[44] J. Välijärvi, P. Kupari, P. Linnakylä, P. Reinikainen, S. Sulkunen, J. Törnroos, and I. Arffman, The Finnish success in PISA - and some reasons behind it 2. Finnish Institute for Educational Research, University of Jyväskylä, 2007.

[45] N. Alloway, P. Freebody, P. Gilbert, and S. Muspratt, Boys, literacy and schooling. Expanding the repertoires of practice. Commonwealth of Australia, Canberra, 2002.

[46] L.K. Rhodes and N.L. Shanklin, Windows into literacy. Assessing learners $K-8$. Heinemann, Portsmouth, $\mathrm{NH}, 1993$.

[47] T. Merisuo-Storm, "Primary school students' reading comprehension skills", In Education in Finland. Taiwan National Institute of Educational Resource and Research, Taipei, 2010, 267-286. 